\title{
Research on Employment and Entrepreneurship of College Students under the Background of "Internet +" Era
}

\author{
Rui Wang ${ }^{1, a^{*}}$, Shuang Wang ${ }^{1, b}$ \\ ${ }^{1}$ College of Mechanical and Electric Engineering, Changchun University of Science and \\ Technology, Changchun 130022, China. \\ a45816026@qq.com, b1282105565@qq.com
}

\begin{abstract}
With the "Internet + " action plan is put forward and implement steadily, and modern manufacturing in combination with the Internet of things, big data and cloud computing, to promote the Internet finance, industry, the development of Internet, electronic commerce health, local university students have more opportunities in employment, employment entrepreneurship have more choice. This article from the local college students employment, entrepreneurship in the employment of college students "Internet + " to local colleges entrepreneurial opportunities and challenges brought about by the two aspects of the current university students' employment entrepreneurship environment compares the profound analysis, through the questionnaire survey form, such as mining under the background of "+" Internet age characteristics and advantages of local college students employment entrepreneurship.
\end{abstract}

Keywords: "Internet +", employment, entrepreneurship, research.

\section{Introduction}

With the rapid development of Internet and network information technology, more and more people use smart phones and all kinds of modern mobile devices, mobile intelligent terminal has been highly popular, China's Internet industry has gained rapid growth of college students for our society in one of the most dynamic and creative group, and their employment and entrepreneurship has been the focus of concern to the party and state.

"Internet + " is mainly refers to the manufacturing of the modern Internet of things, big data and cloud computing, to promote the Internet finance, industry, the development of Internet, electronic commerce health, and guide its development in the direction of internationalization. At present, the information economy accounted for the proportion of $4 \%$ of GDP, the new employment entrepreneurship derived from its form, provides graduates with a broader development areas and more opportunities for development, to innovation plays an important role in promoting social development, and intensify the research is desperately needed.

\section{Analysis on Employment and Entrepreneurship of College Students}

As Internet connection to people's life more and more closely, "Internet + " entrepreneurial model of employment is to rich, college students because of its advanced life consciousness and vigorous spirit of innovation, the system of professional knowledge, rich information channels, making it a "+" Internet innovation the main participants in the venture.On the one hand, the number of college graduates increases year by year with the expansion and reform of colleges and universities. On the other hand, there are some problems between the requirement of enterprise post skills and the comprehensive quality ability of college students. Moreover, the competitiveness of ordinary college students is weaker than that of college graduates affiliated to the central ministries and commissions, which makes the employment situation of ordinary colleges and universities more serious. Although both the state and the general public attach great importance to the employment and entrepreneurship of college students and have issued many preferential policies, it is still difficult for ordinary college graduates to start their own businesses. First of all, ordinary colleges and universities lack the relevant professional course guidance for college students and fail to make them understand the relevant preferential policies of the government in detail. Secondly, college students are less aware of career planning and less capable of starting a business. Finally, some families, society and even enterprises 
do not favor and support college students to start businesses, and the entrepreneurial atmosphere is not strong.

"+" Internet and e-commerce, health care, education, tourism, entertainment together from all walks of life, has created the new ecological, the new development of the industry, a large number of innovative entrepreneurial opportunities thus produced. At home and abroad in recent years, college graduates increased year by year, college students' employment pressure to grow, there is no lack of domestic experts and scholars with college students "Internet + " innovative undertaking to do a lot of research in order to more accurately response "Internet + " under the background of the current situation of college students' employment entrepreneurship, the author in changchun university of science and technology, changchun university, jilin agricultural university, 600, head of the start-up and graduate employment students students has carried on the questionnaire and fill in the questionnaire using secret way, recycling questionnaire 546, recovery rate was $91.5 \%$, the effective questionnaire 546, rate of valid questionnaire is $91 \%$, The basic information is as follows:

(1) from the perspective of the gender of the employed and entrepreneurial personnel, 409 males, accounting for $74.9 \%$, were included in the questionnaire collected; There were 137 girls, or $25.1 \%$ of the total. The proportion of male students is relatively high, which has something to do with the survey in science and technology schools.

(2) according to the educational background of the respondents, senior students account for $30.04 \%$, junior students account for $10.62 \%$, sophomore students account for $14.65 \%$, and freshmen account for $44.69 \%$. We can see that a freshman just entered the campus for future employment entrepreneurship have very high enthusiasm and longing, so the most proportion of senior student for employment and entrepreneurship have certain consciousness, desperately want to know how the future, so the survey will also actively participate in.

(3) from the perspective of the satisfaction of participants for their major, the majority of students to learn professional very satisfied, the proportion about $27.84 \%$, satisfaction of students accounted for $38.36 \%$, generally satisfactory $(29.12 \%)$, very dissatisfied with $5.68 \%$, according to this phenomenon, the author has carried on the detailed interview to the student, from the point of the interview results, most students in university, have a clear direction to their future development, is to know what you like, also know what you want, can clear their goals, for the purposes of this professional is also very interested in, interest is the best teacher, What you like, you will learn well, and you will be satisfied.

In the collected questionnaire, the employment direction of college students is mainly related to their major, and their interests and interests will also be taken into account. For science and engineering students, about 80 percent of the first jobs they choose focus on personal development. In the process of innovation, entrepreneurship and employment of college students, the most important requirement for college students' quality is to have the spirit of challenge and good communication skills.

\section{Analysis on Employment and Entrepreneurship Environment of College Students in the "Internet Plus" Era}

In the era of "Internet plus", the employment and entrepreneurship opportunities of ordinary college students have increased their awareness of employment and entrepreneurship. The era of "Internet plus" enables all available resources in society to be recombined to the maximum. In this context, the ordinary university students through rational judgment of its own resources to choose what way of employment and analysis of the employment situation, actively engage in production activities to the suitable for their work, become the new production on, the operator of the project. "Internet + " from contact with the outside world more faster, update the more advanced ideas, knowledge, idea, makes the ordinary university students have more resources and information to understand and realize employment entrepreneurship, awareness of employment entrepreneurship more clearly. 


\section{The Characteristics and Advantages of Employment and Entrepreneurship of College Students in the Era of "Internet Plus"}

The era of "Internet plus" has created a new development model by integrating traditional industries with new networks through big data and information communication technologies and providing Internet platforms. Internet not only achieved its in a collection of the social resource allocation and improve the effect and and apply its new achievements in the various fields of social economy, create more new industries and for social productivity, "+" Internet age for ordinary college students employment entrepreneurship provides a more broad prospects.

\section{Conclusions}

To sum up, through the "+" Internet age the employment of college students entrepreneurship research, to find that under the background of "Internet + " cultivating university students' employment ability, not just the government's target of department and education department, it should be implemented.College students should give full play to their own subjective initiative, also should change their concept of employment entrepreneurship, by the advantage of Internet to improve their ability of corresponding, through employment entrepreneurship to create more value for the society.

\section{Acknowledgments}

The author would like to thank the leaders of jilin provincial education department and changchun university of technology's student affairs office for their guidance and help from colleagues of the school of mechanical and electrical engineering

\section{References}

[1]. Xu shuai.Exploration on the cultivation of entrepreneurial ability of college students under the background of "Internet +" [J]. Ginseng flower, 2016, 20.

[2]. Zhang ruyang, ma xiaoli. Research on strategies for cultivating college students' entrepreneurial and employment ability under the condition of "Internet +" [J]. Intelligence, 2016. 32.

[3]. Bai yan, zhang zhiyi. Development strategy and application system platform of college students ' employment and entrepreneurship capability under the background of "Internet + big data" [J]. Heilongjiang science and technology information, 2016 (1).

[4]. Wei zixuan, dong xiangyong. New ideas of education for college students' entrepreneurship in $\mathrm{t}$ he era of big data [J]. Journal of Bahia University of aerospace industry, 2016 (4).

[5]. His di. Innovation and entrepreneurship of college students in the context of "Internet plus" [J]. China management informatization, 2016.

[6]. Huang yongrong. Regional employment: the new development of employment mechanism for college students in China [J]. Heilongjiang higher education research, 2010 (4). 